\title{
Risk of Factor on History Disease with Nutritional Status On Toddlers Aged 24-59 Months in Pidie Jaya District
}

\author{
${ }^{1 *}$ Zuhra Tun Nur, ${ }^{2}$ Suryana \\ ${ }^{1}$ Nutrition Department, Politeknik Kesehatan Kemenkes Aceh, Indonesia, zuhratunnur@ gmail.com \\ ${ }^{2}$ Nutrition Department, Politeknik Kesehatan Kemenkes Aceh, Indonesia, bundanafisgibran@gmail.com \\ *Coresponding author: Zuhra Tun Nur, e-mail : zuhratunnur@ gmail.com
}

\begin{abstract}
The nutritional problem has happened in Indonesia. One of them is toddler malnutrition. Children who are malnourished have a low immune system. Thus it is susceptible to infectious diseases. Factors that can prevent nutritional problems in toddlers include the age of weaning and the toddler's immune system. Breastfeeding until the two-years-old, weaning, and body resistance will also affect the toddler's nutritional status. The research aimed to identify the risk factors of disease history on toddler stunting's nutritional status in Pidie Jaya District. The research's implementation was descriptive-analytic with a cross-sectional research design with a sample size of 34 people - data on weaning patterns and disease history obtained through interviews with questionnaires. Anthropometry measurements obtained the nutritional status data of toddlers. Analysis used chi-square test. Based on the results, most of the $14.7 \%$ of toddlers had a history of fever, $52.95 \%$ of unwilling toddlers. Toddlers with well nutritional status with weight-for-age index $64.7 \%$, skinny nutritional status with weight-for-height index $55.9 \%$, short nutritional status with height-for-age $52.9 \%$, and regular dietary status with BMI-for age index $73.5 \%$. Conclusion there was an influence of children's history disease in the last three months on nutritional status in the index height-for-age P-value $=<0.015(<0.05)$ with OR 6.0, but there was no influence of sick history on nutritional status with index weight-for-age, weight-for-age and BMI-for-age (P-value >0.05). It was important for the mother to implement a healthy lifestyle, environmental hygiene, and hygiene of the food history to become better.
\end{abstract}

\section{ARTICLE INFORMATION}

Submitted: $10 / 03 / 2021$

Revised: 05/05/2021

Accepted: 17/05/2021

Publish Online: 26/05/2021

Keywords:
History of Disease
Nutritional Status
Toddlers

Keywords:

Nutritional Status

Toddlers

How to cite this article: Nur, Z. T., Suryana. (2021). Risk of Factor on History Disease with Nutritional Status On Toddlers Aged 24-59 Months in Pidie Jaya District. JNS: Journal of Nutrition Science, 2(1), 7-12

\section{Introduction}

Anthropometry is a method used to assess the size, proportion, and composition of the human body. Children's Anthropometry standard is a collection of data on height, balance, body composition as a reference to assess the nutritional status and growth trends of children. In evaluating children's nutritional status, among others, by using index weight-for-age, height-for-age, weight-for-height, and BMI-for-age. Malnutrition can describe with indicators weight-forage, stunting/short can describe with indicators heightfor-age, and skinny nutritional status can describe with indicators weight-for-height or BMI-for-age (Itza et al. 2020) (Permenkes RI No. 2, 2020).

Nutritional problems in toddlers are pretty high. It finds on all indicators with anthropometry measurements. Based on the Basic Health Research report in 2013, the prevalence of skinny/bad nutrition problems was $25.3 \%$, and stunting reached $37.2 \%$ in Indonesia. The figure showed that issue of public health in the moderate to even nutritional category with weight-for-age index because it was in the range of $20-29 \%$, while the short/concise status with the height for age index was in the high-level category because it was in the field of 30-39\% (Riskesdas, 2013).

Nutritional problems in toddlers and are caused by inadequate dietary intake are also affected by infectious diseases. Children who get enough food but often have diarrhea or ARI and fever can end up experiencing malnutrition. In children with insufficient consumption, causing their immune 
systems weaken. In such circumstances, the child is vulnerable to diseases that can reduce his appetite, and eventually, the child suffers from malnutrition (Khomsan et al., 2013.

Infectious diseases are diseases derived from viruses, fungi, or bacterial infectious diseases in toddlers, namely ARI disease, worms, chickenpox, and diarrhea. Infectious diseases can cause toddlers to decrease. The food intake of toddlers consists of macronutrients, namely energy, protein, fat, and carbohydrates, while micronutrients consist of vitamins and minerals (Gerungan et al, 2013).

Based on research conducted by Rusmiati, there was a relationship between the length of diarrhea incidence and the nutritional status of toddlers according to weight-for-age at RSU Dr.Tengku Mansyur Tanjungbalai Medan (Rosari et al. 2013). The results conducted by Nurcahyo et al in Bogor Regency, also showed that toddlers aged 12-59 months that the more often the frequency of pain experienced, toddlers' nutritional status according to weight-for-age would be worse (Nurcahyo and Briawan, 2010).

Another study conducted by Martianto et al. in Lembata Regency, East Nusa Tenggara, showed that infectious diseases with children's nutritional status had a significant relationship. Malnutrition could be caused by lack of food intake, infection, and poor parenting patterns, especially food intake (Supriatin, 2004). It can be concluded that the frequency of illness history experienced by infants, toddlers, and children would further increase the mortality rate. It is one of the primary health indicators that influenced the increase or decrease in infant, toddler, and child mortality.

Nutrition in toddlers is indispensable to support their growth and development. Deficiency nutrition will inhibit the synthesis of DNA proteins that cause inhibited formation of brain cells that will further inhibit their brain development. Its caused protein synthesis can be inhibited. Thus the size of the brain is smaller, although the number of cells is expected. Maternal also has an essential role in overcoming nutritional problems, especially in terms of family nutrition intake, ranging from food preparation and food selection to the food menu. It is known that optimal nutrient intake supports their growth either physically, psychically or motor. In other words, optimal nutrient intake at this time is a picture of optimal growth and development in the future (Rambu et al. 2017).

This study aimed to determine the risk factors of illness history to nutritional status with index weightfor-age, weight-for-height, height-for-age, and BMI- for-age in toddlers in Subdistrict Pante Raja Pidie Jaya.

\section{Method}

The research was descriptive-analytics with a crosssectional research design conducted in the Panteraja Health Center, Pidie Jaya Regency in June 2020. The population of this study was all toddlers in the Village of Panteraja Mosque. The sample of this study was toddlers aged 24-59 months which amounts to 34 toddlers. Sampling using the purposive technique with several criteria, namely toddlers aged 24-59 months, and willing to participate in research activities.

Techniques of data collection obtained by interview using questionnaires and children's height were carried out anthropometry measurements. Data analysis used frequency distribution tables to get general information about the characteristics of samples and respondents. The chi-square test used $95 \%$ of trust ( $\alpha$ $=0.05)$.

\section{Results}

\section{A. Characteristic of Sample and Respondence}

Sample characteristics of this study included age and gender toddlers. At the same time, the features of respondents had age, occupation, and education.

Table 1. Frequency Distribution of Characteristics Sample and Respondent

\begin{tabular}{|l|c|c|}
\hline Characteristic of Sample & N & Percentage (\%) \\
\hline Age & & \\
$24-36$ months & 12 & 35,2 \\
$37-59$ months & 22 & 64,7 \\
Total & $\mathbf{3 4}$ & $\mathbf{1 0 0}$ \\
Sex & 17 & 50 \\
Men & 17 & 50 \\
Women & $\mathbf{3 4}$ & $\mathbf{1 0 0}$ \\
Total & & \\
\hline Characteristic of & & \\
Respondence & & \\
Age & 16 & 47 \\
<30 Years & 18 & 53 \\
>30 Years & $\mathbf{3 4}$ & $\mathbf{1 0 0}$ \\
Total & & \\
Occupation & 24 & 70,6 \\
Non-working & 10 & 29,4 \\
Working & $\mathbf{3 4}$ & $\mathbf{1 0 0}$ \\
Total & & \\
Education & 4 & 11,7 \\
Low & 25 & 73,5 \\
Middle & 5 & 14,7 \\
High & $\mathbf{3 4}$ & $\mathbf{1 0 0}$ \\
Total &
\end{tabular}

Vol. 2, No. 1, May, 2021

doi: https://doi.org/10.35308/jns.v2i2.3347
JNS: Journal of Nutrition Science

P- ISSN : 2723-2867, E-ISSN : 2723-2875 
The samples in this study were toddlers aged 24-59 months, and the respondent was the mother of a toddler. Based on table 1, the number of samples was 34. The highest proportion was children aged 37-59 months $(64.7 \%)$. The ratio of male and female genders is equal $(50 \%)$.

More than half the proportion of mothers over the age of $30(53 \%)$ and most had a status of jobless $(70.6 \%)$ and had educational quality in the middle category of junior and high school $(73.5 \%)$.

\section{B. History of Disease Sample}

Table 2. Distribution of Sample Frequency History of Disease

\begin{tabular}{ccc}
\hline History of Disease & N & Percentage (\%) \\
\hline Yes & 16 & $\mathbf{4 7 , 0}$ \\
No & 18 & $\mathbf{5 2 , 9}$ \\
\hline Total & $\mathbf{3 4}$ & $\mathbf{1 0 0}$
\end{tabular}

Table 2 above showed that the more significant proportion of toddlers undisease $52.9 \%$ and toddlers illness was $47 \%$. Toddlers get diarrhea, and ARI as big as $37,5 \%$ and $62,5 \%$, with the historical cases of ARI were coughs, colds, and fevers. The data on toddlers' illness was presented in diagram 1.

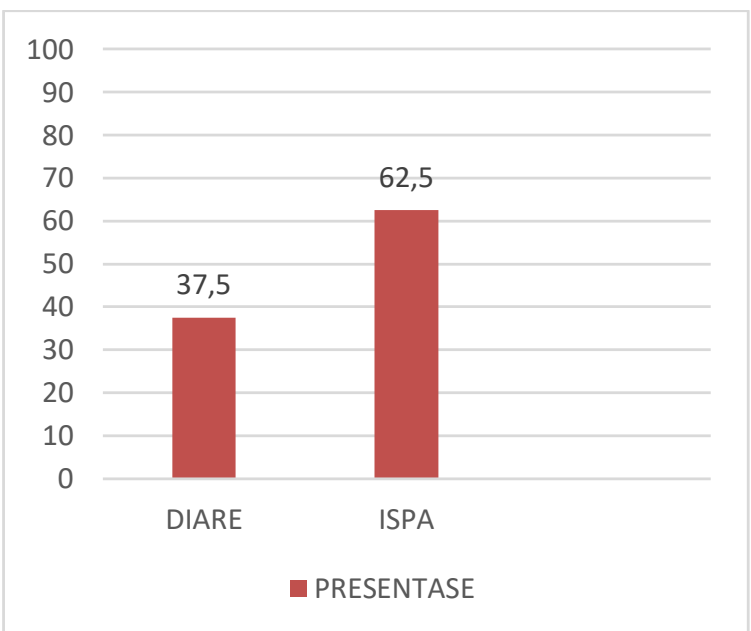

Diagram 1. History of diarrhea and ARI

\section{Nutritional Status}

Table 3. Frequency Distribution of Nutritional Status of Toddlers

\begin{tabular}{lll}
\hline \multicolumn{1}{c}{$\begin{array}{c}\text { Nutritional Status of } \\
\text { Toddlers }\end{array}$} & $\mathbf{n}$ & $\mathbf{\%}$ \\
\hline Weight-for-Age & 12 & $\mathbf{3 5 , 3}$ \\
Underweight & 22 & $\mathbf{6 4 , 7}$ \\
Normal (references) & $\mathbf{3 4}$ & $\mathbf{1 0 0}$ \\
Total & & \\
\hline
\end{tabular}

\begin{tabular}{lcc} 
Weight for Height & & \\
Moderate Wasting & 19 & $\mathbf{5 5 , 9}$ \\
Normal (references) & 15 & $\mathbf{4 4 , 1}$ \\
Total & $\mathbf{3 4}$ & $\mathbf{1 0 0}$ \\
& & \\
Height-for-Age & & \\
Moderate Stunting & 18 & $\mathbf{5 2 , 9}$ \\
Normal (references) & 16 & $\mathbf{4 7 , 1}$ \\
Total & $\mathbf{3 4}$ & $\mathbf{1 0 0}$ \\
& & \\
BMI-for-Age & & \\
Underweight & 9 & $\mathbf{2 6 , 5}$ \\
Normal (references) & 25 & $\mathbf{7 3 , 5}$ \\
Total & $\mathbf{3 4}$ & $\mathbf{1 0 0}$ \\
\hline
\end{tabular}

Nutritional status in this study was assessed based on indeks weight-for-age, weight-for-height, height-forage, and BMI-for-age. Table 3, it could be known that the most significant proportion of samples had well nutritional status with weight-for-age index $(64.7 \%)$, nutritional status skinny with weight-for-height index $(55.9 \%)$, short nutritional status with height-for-age index (52.9\%), and standard dietary status with BMIfor-age index $(73.5 \%)$.

\section{Effect of History of Disease on Nutritional status}

Table 4 showed the most significant percentage of toddlers who had no history of disease with under nutritional status was $44.4 \%$. In comparison, those who had a history of illness with a well nutritional status were $75 \%$. Skinny toddlers who had a history of disease were $68.8 \%$, and the normal category was $55.6 \%$ who had no history of illness. The Height for age index who had a history of pain in the short class was $75 \%$. At the same time, toddlers who did not account for disease in the normal category were $66.7 \%$. The BMI for age index in the skinny category was $37.5 \%$ who had a disease history. Meanwhile, there was no history of disease $83.3 \%$ in the normal category.

On the other hand, the result also showed that the infection had a significant effect on nutritional status according to the Height for age index with a P-value: 0.015 or $<0.005$. Furthermore, it could be seen that toddlers who had a history of disease in the last three months with a duration of more than two times had six times higher risk of having a short nutritional status than those who have not it. Meanwhile, the infection status variable did not significantly influence nutritional status according to weight-for-age, weight- 
for-height, and BMI-for-age. No effect was known

because the $\mathrm{p}$-value was $>0.05$.

Table 4. Effect of History of Disease on Nutrition Status Toddlers

\begin{tabular}{|c|c|c|c|c|c|c|c|c|}
\hline \multirow{3}{*}{ Nutritional Status } & \multicolumn{6}{|c|}{ History of Disease } & \multirow{3}{*}{ OR } & \multirow{3}{*}{ P-Value } \\
\hline & \multicolumn{2}{|c|}{ Yes } & \multicolumn{2}{|c|}{ No } & \multicolumn{2}{|c|}{ Total } & & \\
\hline & $\mathbf{n}$ & $\%$ & $\mathbf{n}$ & $\%$ & $\mathbf{n}$ & $\%$ & & \\
\hline \multicolumn{9}{|l|}{ Weight-for-Age } \\
\hline Underweight & 4 & 25 & 8 & 44,4 & 12 & 35,2 & 0,417 & \\
\hline Normal (references) & 12 & 75 & 10 & 55,6 & 22 & 64,7 & $0,09-1,8$ & 0,236 \\
\hline Total & 16 & 100 & 18 & 100 & 34 & 100 & & \\
\hline \multicolumn{9}{|l|}{ Weight-for-height } \\
\hline Moderate Wasting & 6 & 37,5 & 3 & 16,7 & 9 & 26,4 & 2,750 & \\
\hline Normal (references) & 10 & 62,5 & 15 & 83,3 & 25 & 73,5 & $0,6-11,2$ & 0,154 \\
\hline Total & 16 & 100 & 18 & 100 & 34 & 100 & & \\
\hline \multicolumn{9}{|l|}{ Height-for-Age } \\
\hline Moderate Stunting & 12 & 75 & 6 & 33,3 & 18 & 52,9 & 6,0 & \\
\hline Normal (references) & 4 & 25 & 12 & 66,7 & 16 & 14,0 & $1,3-26,8$ & $0,015^{*}$ \\
\hline Total & 16 & 100 & 18 & 100 & 34 & 100 & & \\
\hline \multicolumn{9}{|l|}{ BMI-for-Age } \\
\hline Underweight & 6 & 37,5 & 3 & 16,7 & 9 & 26,4 & 3,0 & \\
\hline Normal (references) & 10 & 62,5 & 15 & 83,3 & 25 & 73,5 & $0,6-14,8$ & 0,169 \\
\hline Total & 16 & 100 & 18 & 100 & 34 & 100 & & \\
\hline
\end{tabular}

*Significant on $\mathrm{p}$-value $<0.05$

\section{Discussion}

This research was conducted on toddlers aged 24-59 months in the Village of Panteraja Mosque, Pidie Jaya Regency. The prevalence of the number of toddlers who had a history of disease in this study was relatively high, $47.05 \%$. Furthermore, nutritional problems in toddlers measured by using anthropometry were also relatively high either by using the weight-for-age index of the undernourished nutrition category (35.3\%), the height-for-age index of the short category/stunting (52.9\%), the weight-forheight index of the skinny type (55.9\%) and the lean category BMI-for-age index (26.5\%).

The disease history was measured in the last three months with the frequency of disease above two times. The disease's history consisted of diarrhea and ARI with several symptoms of cough, cold, and fever. The most common type of disease experienced by toddlers was ARI, cough, cold, and fever symptoms.

Childhood malnutrition was always associated with a specific vitamin-mineral deficiency and was related to certain micronutrients and macronutrients. In recent years there had been a lot of research on the impact of nutrient intake deficiency, starting from the increased risk of infectious diseases and deaths that could inhibit growth and mental development [8].

The nutritional status could be determined through laboratory examination or anthropometry. Anthropometry was the easiest way of determining nutritional status. Height-for-age, weight-for-age, and weight-for-height were recommended as good indicators for determining toddlers' nutritional status. At high dietary quality, weight-for-age was healthy nutrition $64.7 \%$. In the nutritional group of weight-forheight skinny category, as much as $55.9 \%$. At the nutritional status of height-for-age, short toddlers $52.9 \%$, and in the nutritional status of BMI-for-age, typical toddlers are $73.5 \%$.

This study's results did not show a significant influence between the history of disease on nutritional status with index weight-for-age, weight-for-height, and BMI-for-age. However, significantly influenced by nutritional status with index height-for-age. It was suspected because the child's disease duration was not too long, so the child's sick history does not significantly affect the nutritional status with the index of weight-for-age, weight-for-height, and BMI-forage. Other allegations were also caused by other factors that affect the child's nutritional quality, namely nutrient intake and parenting patterns. In contrast to other studies, there was a negative relationship between the frequency of diarrhea and ARI incidence and infants' nutritional status based on weight-for-age, height-for-age, and weight-for-height.

Vol. 2, No. 1, May, 2021 
It showed that the more often children had diarrhea and ARI, the worse the nutritional status based on weight-for-age, height-for-age, and weight-for-height (Nurcahyo and Briawan, 2010).

Applying the principle of good feeding in a sick child, such as feeding a smaller amount with a frequent duration and paying attention to food texture, could meet the child's nutritional intake during illness. Sick children need to pay attention to the best possible intake of nutrients, including the information of vitamins and minerals, namely by providing various dishes such as vegetable porridge that had been softened, giving formula milk, giving fruit that had also been crushed. The actions of the parents to keep the child experiencing normal nutritional status (Wardani, 2012).

The history of disease in this study significantly affected nutritional status with height-for-age index (P-value: <0.05). Toddlers who had a history of illness in the last three months with a duration of more than two times were at risk of having nutritional status with height-for-age index with stunting category, compared who had no history of the disease. Infectious diseases were a factor that affects the nutritional quality of toddlers (Handayani et al. 2017). Furthermore, in addition to infectious diseases, foster care patterns were also significantly associated with toddlers' nutritional status (Martianto, 2006). The three main factors that affect children's nutritional status were aspects of consumption, child health, and psychosocial care. The emergence of dietary problems in toddlers was influenced by many interrelated factors (Martianto, 2006).

According to WHO, linear growth disorder or often called stunting was caused by the accumulation of long-standing episodes of stress against inadequate food intake and infection, which was then not offset by catch-up growth characterized by a deficit in height or body length of less than -2 SD Z score (Organization UNCFWH, 2004). Infectious factors influenced stunting through 2 ways that the incidence of infection would directly affect the metabolism of nutrients in the body, including would inhibit the absorption of nutrients. The incidence of the child's disease would affect the child's appetite becomes less so that these two things would impact the nutritional status of the child or stunting. Food intake and infectious diseases and both encourage each other (affect). Babies who do not get proper breast milk and MP-ASI had low endurance, so it was easy to get infected. Otherwise, infections such as diarrhea and upper respiratory tract infections (ARI) result in nutrient intake that the body cannot absorb properly. section is also a major part of the research articles and is also usually the longest part of an article. Discussion of the research presented in this section are the result. The process of data analysis such as statistical calculations or other processes for the achievement of its research. Please present the discussion narratively.

\section{Conclusion and Suggestion}

There was a significant influence between the history of infection studies on nutritional status and the height-for-age index, but there was no significant influence on weight-for-age, weight-for-height, and BMI-for-age indexes. Thus, it is essential to maintain the child's health, not experience illness or infection, affecting the child's nutrient intake and nutritional status.

\section{Conclusion}

There was a significant influence between the history of infection studies on nutritional status and the height-for-age index, but there was no significant influence on weight-for-age, weight-for-height, and BMI-for-age indexes. Thus, it is essential to maintain the child's health, not experience illness or infection, affecting the child's nutrient intake and nutritional status.

\section{Acknowledgement}

This research was supported by the Aceh Polytechnic of Health, thanks to all parties who had participated, namely the Village Government, Respondents, and enumerator team.

\section{References}

A. Rosari, E. A. Rini, and M. Masrul. (2013) Hubungan Diare dengan Status Gizi Balita di Kelurahan Lubuk Buaya Kecamatan Koto Tangah Kota Padang. J. Kesehat. Andalas. vol. 2, no. 3, p. 11. doi: 10.25077/jka.v2i3.138.

G. P. Gerungan, N. S. Malonda, and D. V Rombot, . (2013). Hubungan Antara Riwayat Penyakit Infeksi dengan Kejadian Stunting pada Anak Usia 13-36 bulan di Wilayah Kerja Puskesmas Tuminting Kota Manado," J. Penyakit Infeksi dan Stunting, vol. 392, pp. 0-5.

Handayani, D. S., Sulastri, A., Mahira, T., \& Nurhaeni, N. (2017). Penyimpangan Tumbuh Kembang Pada Anak Dari Orang Tua Yang Bekerja. Jurnal Kperawatan Indonesia, 49.

K. Nurcahyo and D. Briawan. (2010). Konsumsi Pangan, Penyakit Infeksi, Dan Status Gizi Anak Balita Pasca Perawatan Gizi Buruk. J. Gizi dan 
Pangan. vol. 5, no. 3, p. 164. doi: 10.25182/jgp.2010.5.3.164-170.

Khomsan A. Anwar F. Hernawati N. Suhanda NS. Wardito O. (2013). Tumbuh Kembang dan Pola Asuh. Bogor (ID): Institut Pertanian Bogor.

Martianto D. (2006). Kalau Mau Sehat, Jangan Tinggalkan Kebiasaan Sarapan. http:/www.republika.co.

Mulyani, I., Marniati, Ayunda, H. M. (2020). The Relation of LBW, Mother's Height with The Accidence of Stunting in the Children Among 6-24 months in Aceh Barat Regency. JNS: Journal of Nutrition Science, 1(2), 33-37

Nurcahyo K, Briawan D. (2010). Konsumsi Pangan, Penyakit Infeksi, dan Status Gizi Anak Balitia Pasca Perawatan Gizi Buruk. Jurnal Gizi dan pangan, Vol 5 (3): 164-170.

Organization UNCFWH. (2004). Low Birthweight: Country, Regional and Global Estimates. New York: UNICEF.

Peraturan Menteri Kesehatan Republik Indonesia. Nomor 2. (2020). Standar Antropometri Anak
R. Rambu Podu and Nuryanto. (2017). Pola Asuh Pemberian Makan Pada Balita Stunting Usia 612 Bulan di Sumba Nusa Tenggara Timur. J. Nutr. Coll. vol. 6, pp. 83-89. [Online]. Available:

https://media.neliti.com/media/publications/20 0664-pola-asuh-pemberian-makan-pada-bayistun.pdf.

Riskesdas (Riset Kesehatan Dasar). (2013). Badan Penelitian dan Pengembangan Kesehatan Kementerian Kesehatan RI Tahun 2013

Supriatin A. (2004) Analisis faktor-faktor yang mempengaruhi pola asuh makan dan hubungannya dengan status gizi balita (skripsi). Bogor: Institut Pertanian Bogor.

Wardani MS. (2012). Faktor-Faktor yang Mempengaruhi Status Gizi Balita di RW 06 Kelurahan Pancoran Mas Kecamatan Pancoran Mas- Depok. Jakarta: Universitas Indonesia. 